\title{
Modelling the influence of Culture on Entrepreneurial Competencies and Business Success of Women Micro-entrepreneurs in the Informal Sector of the Economy
}

\author{
Nuraini Hashimu Salaudeen ${ }^{1}$, Bello Garba Kofar-Sauri ${ }^{2}$ \\ ${ }^{1,2}$ Umaru Musa Yar'adua University, Katsina, Nigeria. \\ salaudeen.nuraini@umyu.edu.ng \\ bello.garba@umyu.edu.ng
}

\begin{tabular}{ll}
\hline ARTICLEDETAILS \\
\hline History \\
Received $\quad:$ August \\
Revised Format & : September \\
Accepted $\quad:$ October \\
\hline
\end{tabular}

Keywords :

business success, entrepreneurial competencies, culture

\begin{abstract}
S
The study examines the effect of culture on the relationship between the dimensions of entrepreneurial competencies and business success of informal women micro-entrepreneurs in northwest geopolitical zone of Nigeria. The study involves both descriptive and inferential statistics. With a random sample of 361 respondents, collected from a population of women micro-entrepreneurs, through the use of questionnaire, the obtained data were analysed with a variance-based structural equation modelling, PLSSEM. Findings revealed that opportunity, relationship, strategic, and organising competencies all have a positive significant impact on business success of the informal women micro-entrepreneurs in Northwest Nigeria. Also, culture was found to moderate the relationship between relationship competencies and business success of the of informal women microentrepreneurs. These findings shows that any developmental programmes geared towards enhancing the performance of informal women microentrepreneurs in northwest Nigeria should focus on improving their entrepreneurial competencies, and it practically illustrates the importance of interpersonal relations, such as, social interactions and networking activities in the business success of informal women micro-entrepreneurs.
\end{abstract}

\section{INTRODUCTION}

Microenterprises are veritable engines of economic dynamics which ensures a sustainable economic survival among the low-income based households in the world. In most developing countries, the operations of informal microenterprises, such as home business, road-sides, or farm based, have played a crucial role in the socioeconomic development of vulnerable families (Al-Mamun, Saufi, \& Ismail, 2016).

Competency refers to the application of different sets of skills, knowledge, and mind-sets in a given professional context (Lan, Verstegen, \& Mulder, 2011), while the use of use of such knowledge, skills, and ability by the entrepreneurs to achieve growth and success in businesses is term as entrepreneurial competencies (Oyeku, Oduyoye, Asikhia, Kabuoh \& Elmo, 2014; Dermol, 2010).

Culture has been reputed to play a central role in field of entrepreneurship, as most behaviours exhibited by entrepreneurs are bounded by it (Hayton, George, \& Zahra, 2002). Hence, the cultural orientation of every individual is very crucial in development of their competencies (Sajilan, \& Tehseen, 2015). Chaiyabut, (2013) asserts that the individual cultural values and beliefs that triggers the human activities which stimulates their competencies.

Although previous researchers (e.g., Sanchez, 2011; Noor, Hasliza \& Siti, 2010; Man et al; 2002; Nasuredin, Halipah, \& Shamsudin, 2016) have reported high level relationship between

*Corresponding Author Email Address: salaudeen.nuraini@umyu.edu.ng 
entrepreneurial competencies and firm's performance, but only few of these studies revealed the effects of entrepreneurial competencies on business success, among the women-led businesses. While most empirical researches on entrepreneurial competencies-performance relationship on women-led businesses were carried out in Europe (e.g, Schneider, 2017; Mitchelmore, Rowley, \& Shiu, 2014; Mitchelmore \& Rowley, 2013), and in some Asian countries (e.g., Al-Mamun, Fazal, \& Zainol, 2019a; Al-Mamun, A. A., Muniady, R., Fazal, S. A., \& Malarvizhi, C. A., 2019b; Zainol, Mamun, Ahmad, \& Simpong, 2018; Lans, Vertegen \& Mulder, 2011), only few of researches were conducted in the sub-Saharan African context (Okpara \& Wynn, 2007). Even, if there exist any such previous studies that had examined such relationship among female-led businesses, the effect of the disaggregated entrepreneurial competencies on business success of women-led business is yet to be fully explore in the subSaharan African context.

In view of dearth of studies among the female-led businesses in the sub-Saharan African, this paper proposed to examine the disaggregated effect of the entrepreneurial competencies on business success of the informal women micro-entrepreneurs in the Nigeria. In addition to this, this paper further contend that, even if there exist any of such previous studies, their findings are inconclusive, which signifies the need for a potential moderator to further explain such relationship between the constructs. Hence, the paper further examines the moderation effects of culture on these dimensions of entrepreneurial competencies on the business success of the informal women micro-entrepreneurs in the Northwest geopolitical zone of Nigeria. This study has by so doing, projects the recommendations of Hughes, Jennings, Brush, Carter, and Welter (2012), on the need to further explore researches on women entrepreneurship, so as to ensure more business participation and success among women entrepreneurs in the emerging economies, particularly, in sub-Saharan African.

\section{LITERATURE REVIEW AND HYPOTHESES DEVELOPMENT}

\subsection{Concept of Business Success}

The term 'success' or 'performance' in the context of business research, are two different words that are often used synonymously to connotes same meaning. Gill and Biger (2012), interchangeably used the term 'success', 'performance', and 'growth' as having same connotation, while no distinction was made between the terms 'success' and 'performance' by Komppula (2004). However, the use of either of these terms in business research, is content specific, as both terms are determined using same criterion of financial or non-financial measures.

The financial measure focused on the use of hard economic measures, such as using revenues, sales turn-over, profitability, return on investment, and employee's number (Simpson, Padmore, \& Newman, 2004) to measure performance, while the non-financial measure focused on the use of motivation, achieving one's personal goals, and aspirations (Gorgievski, Ascalon, \& Stephan, 2011). Nevertheless, at micro business level, both measures of performance are subjectively determined (Laguna, Wiechetek, \& Talik, 2012) through self-reported perceptual data obtained from the entrepreneur (Richard, Devinney, Yip, \& Johnson, 2009). However, studies have shown that the non-financial subjective data often form the basis for assessing the business success of women entrepreneurs (Ahmad, Wilson \& Kummerow, 2011; Walker \& Brown, 2004).

\subsection{Entrepreneurial Competencies}

Entrepreneurial competencies refers to entrepreneurs' traits such as knowledge, motives, capabilities that that lead to the firms' success (Solesvik, 2012). It is one of the important factors that determines the success or failure of micro enterprises. A study by Sanchez (2012) of SMEs reveals that entrepreneurial competencies have both direct and indirect influence on firm's performance in Spain. Ahmad, Ramayah. Wilson, and Kummerow (2010) also has found entrepreneurial competencies as strong predictors of business success of SMEs especially in a 
dynamic and hostile environment. Man and Lau (2000) have identified six competencies areas of entrepreneurial competencies, namely, strategic, relationship, opportunity, organising, commitment, and conceptual competencies. All these competencies areas have been shown to have either direct or indirect effects on SMEs or business performance. Hence, the onus of this study is a focused on these six competencies areas identified by Man and Lau (2000).

\subsubsection{Opportunity recognition competencies}

Opportunity recognition competency is one of the six competency area identified by Man and Lau (2000). As an important attribute of a successful entrepreneur, opportunity recognition competencies entails the identification and selection of the right business opportunity (Santandreu-Mascarell, Garzon, \& Knorr, 2013; Man, Lau, \& Chan, 2002). It focus on entrepreneur's ability to search, develop, and evaluate various superior opportunities that are existing in the market place (Man \& Lau, 2000). Entrepreneurs who are endowed with this form of competencies are perceived as being insightful in their discovery of new ways and new solutions to business problems by due to the critical ways they analyse business problems with a view to preventing risk of business failure (Ulhoi, 2005). However, such entrepreneurs must be on watch out for any possible opportunity and must possess the ability of integrating such opportunities that they have (Tang, Kacmar, \& Busenitz, 2012).

Zainol, et al. (2018) have found opportunity recognition competencies to positively impact the performance of the inform women microenterprises in Ketatan. Also, Nasuredin, et al. (2016) found a significant positive relationship between opportunity competencies and business performance of SMEs in Malaysia. On this note, this study proposed that following hypothesis: $\mathbf{H}_{\mathbf{1}}$ : Opportunity recognition competencies have positive effect on business success of the informal women micro-entrepreneurs

\subsubsection{Relationship competencies}

Relationship competencies relate to the interactions between the entrepreneurs and different categories of people, such as the employees, customers, suppliers, stakeholders, competitors, and even the government, in the course of business operations (Man, et al., 2002). It also relates to a form of interactions or cooperation existing between the entrepreneurs and the environment in which the business is located. Such forms of interactions, which may takes the form of building trust and cooperation between a person-to-person or between an individual a group, or involves making connections, as in communication, persuasion, or use of interpersonal skills or relations to influence others and gain their support (Kaur \& Bains, 2013; Man, et al., 2002).

Relationship competencies such as interactions between entrepreneurs and their customers, employees, family, or friends, are very crucial to successful entrepreneurship, especially at the micro level of business operation (Ratten, 2013). Relationship competencies have been found to have positive effect on business performance of women microenterprises in kelantan (Zainol, et al., 2018). Studies have shown that entrepreneurs skilled in relationship competencies stands a better chance of achieving favourable results in their businesses than those devoid of it (Baron \& Markman, 2003). Based on the above discussion, the following hypothesis was postulated: $\mathbf{H}_{2}$ : Relationship competencies have positive effect on business success of the informal women micro-entrepreneurs.

\subsubsection{Strategic competencies}

Strategic competencies has to do with the processes involved in the establishing, implementing and evaluating the strategies of a firm (Man, et al., 2002). It is an entrepreneurial ability of developing a sound vision for the business. Studies on entrepreneurial competencies have shown that an entrepreneur's ability to have vision for their business is correlated to strategic management (Baum \& Singh, 1994). Hence, entrepreneurs that are endowed with strategic competencies have the tendency of achieving high performance in their business. Thus, strategic 
competencies enables entrepreneurs to plan and implement several tactics and strategies, which are capable of influencing the competitors and customers in the market, and are likely to be proactive in creating their own growth potential (Sparrow \& Makram, 2015). Thompson and Richardson (1996) opined that an alteration in the management component of strategic competencies could result in competitive success for firms operating in a highly competitive environment. Strategic competencies have been found to impact positively on the business performance of SMEs in Malaysia (Nasuredin, et al. 2016). Thus, the study hypothesised as follow:

$\mathbf{H}_{3}$ : Strategic competencies have positive effect on business success of the informal women micro-entrepreneurs.

\subsubsection{Organising Competencies}

Organising Competencies has to do with the way of determining how business performs or carries out its operations. This encompasses the management of the daily affairs of the business operations, which involves planning, the acquisition and allocation of resources, act of delegating, and establishing rules and regulations, as well as leading and motivating the employees (Al-Mamun, 2019b). Organising competencies ensures smoothness in the daily operations of the business and a sustained high performance (Man, Lau, \& Chan 2002). Nasuredin et al. (2016) report a significant positive relationship between organising competencies and SMEs business performance in Malaysia. Based on this, the study proposed that:

$\mathbf{H}_{4}$ : Organising competencies have positive effect on business success of the informal women micro-entrepreneurs

\subsubsection{Commitment Competencies}

Commitment Competencies is one of the attribute of entrepreneurs who struggles to achieve long-term goal with strong devotions, by taking personal initiative, and possessing strong entrepreneurial attitude (Man, Lau, \& Chan, 2002). Commitment competencies serve as a strong demonstration of the entrepreneur's motivation to compete and see their business through to its fruition (Chandler \& Jansen, 1992). Entrepreneurs that possesses commitment competencies make personal sacrifices where necessary, like maintaining a level high energy, working for long hours, and are motivated (Kozan et al., 2012). Commitment competencies serves as an instinct which drives the entrepreneurs to forge ahead in their businesses despite all odds.

Man, Lau, \& Snape (2008), found a direct significant relationship between commitment competencies and business performance of small and medium enterprises in Hong Kong. Zainol et al, (2018) also report a direct positive statistical significance effect of commitment competencies on business performance of women micro enterprises in Kelantan. Furthermore, study on entrepreneurial competencies of female entrepreneurs in developing countries have found commitment competency as one of a critical element in the business success of women entrepreneurs (Permarupan, et al., 2016). Based on these findings, commitment competencies is predicted to have significant relationship with business success. Hence, the below hypothesis was postulated:

$\mathbf{H}_{5}$ : Commitment competencies have positive effect on business success of the informal women micro-entrepreneurs

\subsubsection{Conceptual competencies}

Conceptual competencies refers to a set of not easily identifiable human behaviours that are often considered as significant and essential in entrepreneurial success. Conceptual competencies can be perceived as the outward reflection of an entrepreneur's mental capabilities (Chandler \& Jansen, 1992), which often reflects in the entrepreneur's behavioural ability to automatically make informed decisions about business opportunities, as well as 
absorbing and understanding complex information for business development (Man, et al., 2002).

Conceptual competencies enables the entrepreneurs to think analytically, and to successfully cope with environmental uncertainties (Bird, 1995). This analytical thinking ability helps the entrepreneurs in terms of analysing complex business problems (Man, et al., 2002). According to Man and Lau (2000), conceptual competencies entail an entrepreneur's ability to assess risks, innovate and think intuitively to stimulate new set of ideas and concept (Michalko, 2000). High conceptual competencies have been found to equip entrepreneurs, especially those operating at the micro business level and are faced with numerous challenges that requires quick decisions, with the ability to analyse and solve these problems by taking sound decision under condition of uncertainties (Gupta, 2010).

$\mathbf{H}_{6}$ : Conceptual competencies have positive effect on business success of the informal women micro-entrepreneurs

\subsection{Culture and Business success}

Culture is conceived as an embodiment of basic set of fuzzy assumptions, shared motives, values, and beliefs which in turn, influences the behaviour of every individual member in its interpretation of behaviours of other people (Spencer-Oatey, 2008). As a behavioural conventions that is shared by group of people, culture has greatly impact on all level of entrepreneurship in any given society (Kreiser, Marino, Dickson, \& Weaver, 2010). For instance, a meta-analytic study of previous empirical results has reveal how culture significantly impact on the relationship between entrepreneurial orientation and business success (Frank, Keßler, Fink, 2010).

Defined as collective programming of the mind which helps to distinguish each member of one group or a category of people from another Hofstede (2001), culture affects the entrepreneurial competencies development and behaviours of the entrepreneurs (Tehseen, Sajilan, Ramayah, \& Gadar, 2015). As conceptualised by Hofstede (1980), culture is multidimensional construct comprising power distance, uncertainty avoidance, femininity/masculinity, and collectivism/individualism.

Power distant refers to the extent to which an individual accept that their superior enjoys power than them (Clugston, Howell, \& Dorfman, 2000; Hofstede, 2001). Uncertainty avoidance is the extent to which people feels threatened and tried to prevent uncertain condition by establishing formal rules and opposing contrary views and behaviours (Ergeneli, Gohar \& Temirbekova, 2007). Femininity-masculinity in culture refers to the way people embraces ambitious career aspirations by becoming firm, assertive, competitive and aggressive in their opinions (Hofstede, 2001), and the dimension of individualism-collectivism refers to the extent to which individuals are willing to sacrifice their welfare for the group or vice versa (Wong, \& Tjosvold, 2006). Based on the existing literature, the study proposed that:

$\mathbf{H}_{7}$ : Culture have positive effect on business success of the informal women microentrepreneurs

\subsubsection{The moderating effect of culture}

This paper disaggregated the six entrepreneurial competencies areas identified by Man and Lau (2000), namely, opportunity recognition, relationship, organising, strategic, commitment, and conceptual competencies, to predict the business success of informal women microentrepreneurs in the northwest geopolitical zone of Nigeria. In addition, the study incorporated culture as a contingent variable that moderates the relationship between these disaggregated competency areas to impact business success of the informal women micro-entrepreneurs. Following Baron and Kenny's (1996), the study proposes that culture moderates the relationship between these competency areas and business success and then, hypothesised as follows:

$\mathbf{H M}_{1}$ : Culture moderates the relationship between opportunity competencies and business success of the informal women micro-entrepreneurial in Northwest Nigeria. 
$\mathbf{H M}_{2}$ : Culture moderates the relationship between relationship competencies and business success of the informal women micro-entrepreneurial in Northwest Nigeria.

HM$_{3}$ : Culture moderates the relationship between strategic competencies and business success of the informal women micro-entrepreneurial in Northwest Nigeria.

HM$_{4}$ : Culture moderates the relationship between organising competencies and business success of the informal women micro-entrepreneurial in Northwest Nigeria.

HM$_{5}$ : Culture moderates the relationship between commitment competencies and business success of the informal women micro-entrepreneurial in Northwest Nigeria.

HM$_{6}$ : Culture moderates the relationship between conceptual competencies and business success of the informal women micro-entrepreneurial in Northwest Nigeria

\section{RESEARCH METHODOLOGY}

\subsection{Research design and Sample size}

The study is cross sectional research in nature. Quantitative data were collected through the random sampling technique, from 384 informal women micro-entrepreneurs operating across four states of the Northwest geopolitical zone of Nigeria. These states include Sokoto, Katsina, Kebbi, and Zamfara state. The respondents for the study were drawn from a pool of 1,443,065 informal women micro-entrepreneurs who are registered with small and medium enterprise development agency of Nigeria (SMEDAN, 2014). The sample size for participants were obtained by applying Dillman's (2011) formula for sample size determination. Thus, a total of 384 women entrepreneurs took part in the survey but only 361 questionnaires were found useable for analysis.

As an exploratory study, the paper employed a variance-based structural equation modelling, which is PLS-SEM estimation as the tool of analysis, with the sole aim of maximising the variance explained of the dependent construct of the model. This method of analysis was adopted due its robustness in allowing for a simultaneous estimation of the both measurements and path coefficients of a model.

\subsection{Constructs and Measures}

The three constructs in the model are business success, entrepreneurial competencies, and culture. Questionnaire was used as the main instrument of the study and all the measures for the three constructs were adapted from previous researches. Business success, as the dependent construct, was measured on a 5-item instrument adapted from Ahmad, et al. (2011), nonfinancial measure of business success.

Entrepreneurial competency as the independent construct, is multidimensional construct comprising six dimensions (i.e., strategic, organising, opportunity, commitment, conceptual and relationship competencies). The instrument was adapted from Man, Lau, and Chan (2002). A breakdown of the measure shows that, strategic competencies have 9 items, organising 10 items, opportunity competencies 4 items, commitment 4 items, conceptual 7 items, and relationship 5 items.

Culture, as the contingent construct, is also a multidimensional construct comprising power distance, uncertainty avoidance, femininity/masculinity, and individualism/collectivism (Hofstede, 1980). Nevertheless, this construct was modelled in this paper as a reflectiveformative (i.e., type II) of the hierarchical component model (HCM). All the twenty-two items of the instrument were adapted from the individual cultural value scale (CVSCALE), developed by Dorfman and Howell (1988), consistent with Hofstede's (1980) national culture dimensions. All the 22-item measure were modelled as reflective-formative (i.e., type II) of HCM using a repeated indicator approach, which involves a repeat of all the twenty-two items of the dimensions at lower order components (LOCs), on culture at the higher order component (HOC). This is consistent with extant literature on HCM (Becker, Klein, \& Wetzels, 2012). 
Though, all the four dimensions of culture (Hosfstede, 1980) appeared in the model at LOCs, culture is represented in the model at HOC, as a composite variable (Rowe, 2012).

All the adapted from previous researches and are worded in a simple unambiguous expression so as to make it easy for the respondents to answer the questions being asked. All the items were originally written in English, however, to allow for easy response by the respondents, a backtranslation (Brislin, 1980) was employed, and this led to the reproduction of an exact Hausa version of the questionnaire. All constructs are measured on a 5-point Likert scale, ranging from 1 (strongly disagree) to 5 (strongly agree).

\section{RESULTS}

\subsection{Demographic characteristics}

Table 1 presents the demographic characteristics of the respondents. The information presented were extracted from the questionnaire administered on the 361 informal women microentrepreneurs operating in the four states of northwest geopolitical zone of Nigeria

Table 1: Demographic characteristics of the respondents

\begin{tabular}{|c|c|c|c|c|c|}
\hline Categories & Number & $\%$ & Categories & Number & $\%$ \\
\hline Age & & & Marital status & & \\
\hline 20 years and below & 51 & 14.1 & Single & 64 & 17.7 \\
\hline 21 to 30 years & 125 & 34.6 & Married & 250 & 69.3 \\
\hline 31 to 40 years & 98 & 27.1 & Divorcee & 16 & 4.4 \\
\hline 41 to 50 years & 66 & 18.3 & Widow & 28 & 7.8 \\
\hline Above 50 years & 21 & 5.8 & Total & 361 & 100 \\
\hline Total & 361 & 100 & $\begin{array}{l}\text { Location of } \\
\text { Business }\end{array}$ & & \\
\hline $\begin{array}{l}\text { Education } \\
\text { qualifications }\end{array}$ & & & Home based & 204 & 56.5 \\
\hline No formal education & 80 & 22.2 & External based & 157 & 43.5 \\
\hline $\begin{array}{l}\text { Primary/Secondary } \\
\text { cert. }\end{array}$ & 141 & 39.1 & Total & 361 & 100 \\
\hline NCE/OND & 72 & 19.6 & Years of operation & & \\
\hline HND/Degree & 49 & 13.6 & 3 to 6 years & 99 & 27.4 \\
\hline Master's Degree & 17 & 4.7 & 7 to 10 years & 171 & 47.4 \\
\hline Medical Doctor & 1 & 0.3 & Above 10 years & 91 & 25.2 \\
\hline Total & 361 & 100 & Total & 361 & 100 \\
\hline
\end{tabular}

Source: Author(s) compilation

The demographic profile of the 361 respondents employed in this study as depicted in Table 1, shows that the respondents' age falls within the following age brackets. The highest number of $125(34.6 \%)$ respondents are within the age bracket of 21-30 years. This was followed by 98 $(27.1 \%)$ respondents, who are in the age bracket of 31-40 years, with $66(18.3 \%)$ of the respondents falling within age 41 to 50 years. $51(14.1 \%)$ respondents are below 21 years, with the least respondents 21 (5.8\%), falling above 50 years of age. In terms of marital status, 64 $(17.7 \%)$ respondents are single, while the highest number of respondents, $250(69.3 \%)$, were married. $28(7.8 \%)$ respondents are widow, and $16(4.4 \%)$ are divorcee. In relation to the educational qualifications, a total of $80(22.2 \%)$ respondents are without formal education, while $141(39.1 \%)$ respondents are having either primary or secondary qualification, with 72 (19.6\%) possessing certificate in either education or national diploma. Only $49(13.6 \%)$ are degree holders, while master degree holders are $17(4.7 \%)$ and only $1(0.3 \%)$ possessing degree in medicine. In terms of the location of the business, majority of the respondents 203 (56.5\%) operate home-based businesses, while 157 (43.5\%) operates outsides their homes. In terms of years of business operation, $171(47.4 \%)$ respondents have been operating their business for a 
period of 7-10 years, while $99(47.4 \%)$ have spent between 3-6 years in the business, with only $91(25.2 \%)$ respondents operating for over 10 years.

\subsection{Analysis of direct relationship}

A SmartPLS-SEM software version 3.0 was used in analysing the data obtained from the respondents. The analysis of the direct relationship between the dimensions of entrepreneurial competencies and business success was done in two parts, consistent with Henseler's et al. (2009) two-step approach to path modelling. The first part consists of an analysis of the measurement model, which comprises an examination of the item's reliability of every individual construct, internal consistency reliability, convergence, and discriminant validities of the constructs. The second part is the structural model, is an assessment of the significance of the path coefficient of the direct relationship between the exogenous and endogenous constructs, and an estimation of the $\mathrm{R}^{2}$ of the model.

\subsection{Moderating effect of Culture}

The assessment of the moderating effect of culture on the relationship between the dimensions of entrepreneurial competencies and business success follows Baron and Kenny's (1986) threestep approach to moderation, with first step involving an assessment of the direct relationship between the exogenous and endogenous construct, followed by the effect of contingent variable (moderator) on the exogenous variable, and lastly, the interacting effect between the exogenous and moderating constructs on the endogenous construct.

\section{Measurement Model}

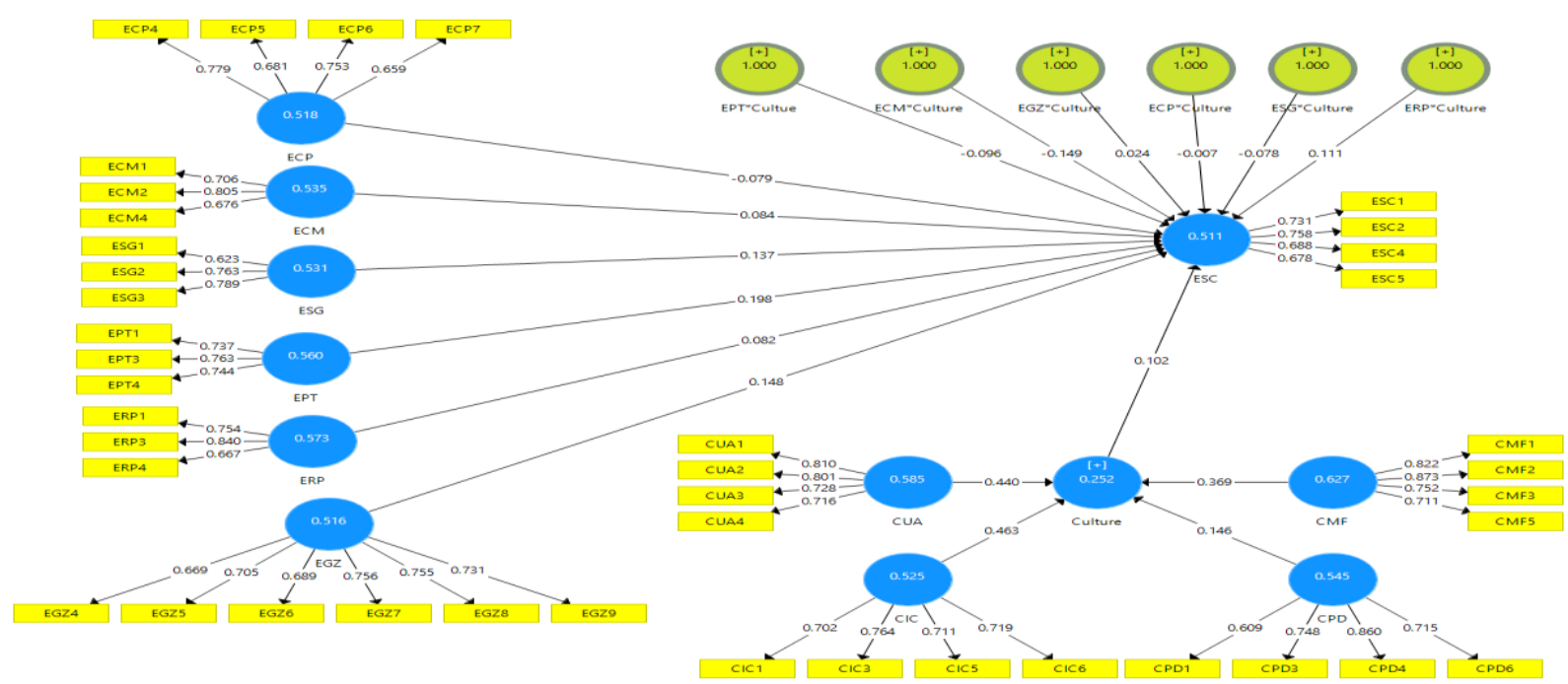

Figure 1: Assessment of the measurement model

Table 2: Convergent Validity

\begin{tabular}{|l|l|c|c|c|c|}
\hline \multicolumn{2}{|l|}{ Convergent Validity } & & & & \\
\hline Constructs & Items & Loadings & $\begin{array}{c}\text { Composite } \\
\text { Reliability }\end{array}$ & $\begin{array}{c}\text { Average Variance } \\
\text { Extracted (AVE) }\end{array}$ & $\mathbf{R}^{\mathbf{2}}$ \\
\hline ESG & ESG1 & 0.623 & 0.771 & 0.531 & \\
\hline & ESG2 & 0.763 & & & \\
\hline & ESG3 & 0.789 & & & \\
\hline ECM & ECM1 & 0.706 & 0.774 & 0.535 & \\
\hline & ECM2 & 0.805 & & & \\
\hline & ECM4 & 0.676 & & & \\
\hline ECP & ECP4 & 0.779 & 0.810 & 0.518 & \\
\hline
\end{tabular}




\begin{tabular}{|c|c|c|c|c|c|}
\hline & ECP5 & 0.681 & & & \\
\hline & ECP6 & 0.753 & & & \\
\hline & ECP7 & 0.659 & & & \\
\hline \multirow[t]{6}{*}{ EGZ } & EGZ4 & 0.669 & 0.865 & 0.516 & \\
\hline & EGZ5 & 0.705 & & & \\
\hline & EGZ6 & 0.689 & & & \\
\hline & EGZ7 & 0.756 & & & \\
\hline & EGZ8 & 0.755 & & & \\
\hline & EGZ9 & 0.731 & & & \\
\hline \multirow[t]{3}{*}{ EPT } & EPT1 & 0.737 & 0.792 & 0.560 & \\
\hline & EPT3 & 0.763 & & & \\
\hline & EPT4 & 0.744 & & & \\
\hline \multirow[t]{3}{*}{ ERP } & ERP1 & 0.754 & 0.800 & 0.573 & \\
\hline & ERP3 & 0.840 & & & \\
\hline & ERP4 & 0.667 & & & \\
\hline \multirow[t]{4}{*}{$\mathrm{CIC}$} & CIC1 & 0.702 & 0.815 & 0.525 & \\
\hline & CIC3 & 0.764 & & & \\
\hline & CIC5 & 0.711 & & & \\
\hline & CIC6 & 0.719 & & & \\
\hline \multirow[t]{4}{*}{$\mathrm{CMF}$} & CMF1 & 0.822 & 0.870 & 0.627 & \\
\hline & CMF2 & 0.873 & & & \\
\hline & CMF3 & 0.752 & & & \\
\hline & CMF5 & 0.711 & & & \\
\hline \multirow[t]{4}{*}{ CPD } & CPD1 & 0.609 & 0.825 & 0.545 & \\
\hline & CPD3 & 0.748 & & & \\
\hline & CPD4 & 0.860 & & & \\
\hline & CPD6 & 0.715 & & & \\
\hline \multirow[t]{4}{*}{ CUA } & CUA1 & 0.810 & 0.849 & 0.585 & \\
\hline & CUA2 & 0.801 & & & \\
\hline & CUA3 & 0.728 & & & \\
\hline & CUA4 & 0.716 & & & \\
\hline \multirow[t]{4}{*}{$\mathrm{BSC}$} & BSC1 & 0.731 & 0.806 & 0.511 & 0.502 \\
\hline & $\mathrm{BSC} 2$ & 0.758 & & & \\
\hline & BSC4 & 0.688 & & & \\
\hline & BSC5 & 0.678 & & & \\
\hline
\end{tabular}

Note: Business success (BSC), commitment competencies (ECM), conceptual competencies (ECP), organising competencies (EGZ), opportunity competencies (EPT), relationship competencies (ERP), strategic competencies (ESG), power distant (CPD), uncertainty avoidance (CUA), individualism-collectivism (CIC), masculinity-femininity (CMF), business success (BSC)

Source: Author's compilation

\subsection{Reliability and validity test}

Table 2 above, shows that the average variance extracted (AVE) values obtained for all constructs are above 0.5 . This is an indication that sufficient convergent validity has been achieved (Hair, Hult, Ringle, \& Sarstedt, 2014). Similarly, table shows that the values of composite reliability of all constructs are above the recommended minimum threshold of 0.7 
(Peng \& Lai, 2012; Hair, et al., 2014). All this suggest that both convergent validity and composite reliability of the measurement model has been achieved. In assessing the discriminant, the values of Heterotrait-Monotrait Ratio (HTMT) in Table 3, shows that the level of correlation among the constructs, falls below the minimum threshold of 0.9. This is an indication that the study has achieved discriminant validity, as all constructs in the model met the minimum conditions. The R-square value of 0.502 indicates that $50 \%$ of the variances in endogenous construct (business success) can be explained by the exogenous constructs (i.e., entrepreneurial competencies and culture)

Table 3: HTMT ratio

\begin{tabular}{lccccccccccc}
\hline Constructs & CIC & CMF & CPD & CUA & ECM & ECP & EGZ & EPT & ERP & BSC & ESG \\
\hline CIC & & & & & & & & & & & \\
CMF & 0.597 & & & & & & & & & & \\
CPD & 0.248 & 0.508 & & & & & & & & & \\
CUA & 0.629 & 0.133 & 0.142 & & & & & & & & \\
ECM & 0.533 & 0.185 & 0.229 & 0.695 & & & & & & & \\
ECP & 0.557 & 0.228 & 0.125 & 0.587 & 0.855 & & & & & & \\
EGZ & 0.565 & 0.165 & 0.145 & 0.656 & 0.762 & 0.704 & & & & & \\
EPT & 0.441 & 0.280 & 0.182 & 0.680 & 0.760 & 0.808 & 0.699 & & & & \\
ERP & 0.572 & 0.281 & 0.183 & 0.686 & 0.820 & 0.746 & 0.762 & 0.747 & & & \\
BSC & 0.620 & 0.157 & 0.112 & 0.674 & 0.814 & 0.619 & 0.669 & 0.829 & 0.705 & & \\
ESG & 0.655 & 0.380 & 0.167 & 0.686 & 0.754 & 0.848 & 0.689 & 0.635 & 0.727 & 0.726 & \\
\hline
\end{tabular}

Note: commitment competencies (ECM), conceptual competencies (ECP), organising competencies (EGZ), opportunity competencies (EPT), relationship competencies (ERP), strategic competencies (ESG), power distant (CPD), uncertainty avoidance (CUA), individualism-collectivism (CIC), masculinity-femininity (CMF), business success (BSC) Source: Author's compilation

\section{Structural model}

Figure 2: assessment of the structural model

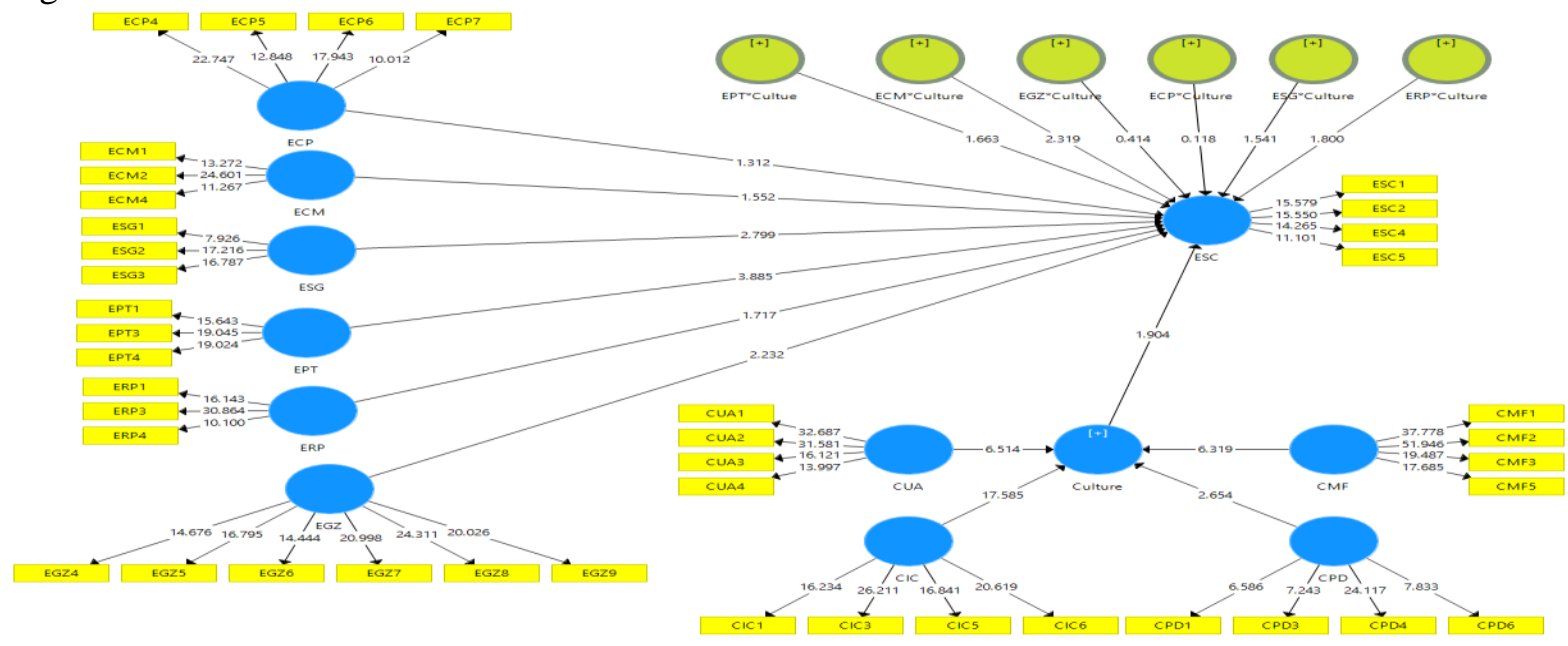

Table 4: Result of the Hypotheses Testing

\begin{tabular}{llccccl}
\hline & & & t- & \\
& Relationships & Std Beta & Std. Error & values & p-values & Decision \\
\hline $\mathrm{H}_{1}$ & ECM -> BSC & 0.084 & 0.054 & 1.552 & 0.061 & Not Supported \\
$\mathrm{H}_{2}$ & ECP -> BSC & -0.079 & 0.060 & 1.312 & 0.095 & Not Supported \\
$\mathrm{H}_{3}$ & EGZ -> BSC & 0.148 & 0.067 & 2.232 & 0.013 & Supported \\
& & & 94 & & &
\end{tabular}




$\begin{array}{lllllll}\mathrm{H}_{4} & \text { EPT -> BSC } & 0.198 & 0.051 & 3.885 & 0.000 & \text { Supported } \\ \mathrm{H}_{5} & \text { ERP -> BSC } & 0.082 & 0.048 & 1.717 & 0.043 & \text { Supported } \\ \mathrm{H}_{6} & \text { ESG -> BSC } & 0.137 & 0.049 & 2.799 & 0.003 & \text { Supported } \\ \mathrm{H}_{7} & \text { Culture -> BSC } & 0.102 & 0.054 & 1.904 & 0.029 & \text { Supported }\end{array}$

Note: Business success (BSC), commitment competencies (ECM), conceptual competencies (ECP), organising competencies (EGZ), opportunity competencies (EPT), relationship competencies (ERP), strategic competencies (ESG).

Source: Author's compilation

\subsection{Path coefficients Analysis}

As shown in Table 4 above, the results of the path coefficients between the individual dimension of entrepreneurial competencies and business success of the informal women microentrepreneurs shows the statistical significance of entrepreneurial competencies (i.e., opportunity, relationship, strategic, and organising) were statistically significant at the 5\% chosen level of significance, indicating that they all have positive significant effect on the business success of the informal women micro-entrepreneur in Northwest Nigeria. Specifically, findings revealed that the coefficient value of opportunity competencies on business success $\left(\mathrm{H}_{1}\right)$ is positive $(\beta=0.198)$, with a ( $p$-values $\left.=0.00\right)$, signifying a positive statistical effect on business success of the informal women micro-entrepreneurs.

Consistently, the coefficient value of relationship competencies on business success $\left(\mathrm{H}_{2}\right)$ shows positive $(\beta=0.047)$ with a $p$-values of 0.043 , indicating that relationship competencies has a positive statistical significant relationship with the informal women micro-entrepreneurs. Similarly, the path coefficient results of strategic competencies on business success $\left(\mathrm{H}_{3}\right)$ shows a positive $(\beta=0.137)$ with a statistical significant $(p$-value $=0.003)$, confirming a strong significant relationship between the two constructs.

Furthermore, findings revealed that the path coefficient value for organising competencies on business success confirms the hypothesised relationship $\left(\mathrm{H}_{4}\right)$ as it revealed a positive $(\beta=0.148)$ with a $p$-values $=0.013$ ). This signifies a positive effect of organising competencies on business success of the informal women micro entrepreneurs.

Conversely, the analysed data failed to lend support to two of the hypothesised relationships. These are the commitment and conceptual competencies on business success of the informal women micro-entrepreneurs. Thus, the results of the path coefficient value of commitment competencies $\left(\mathrm{H}_{5}\right)$ on business success shows a positive $(\beta=0.084)$ but statistically insignificant ( $p$-value $=0.061$ ), in the same way as the coefficient value of conceptual competencies on business success $\left(\mathrm{H}_{6}\right)$, which revealed a negative $(\beta=-0.079)$ value, with a statistical non-significant ( $p$-value $=0.095$ ) on business success of the informal women microentrepreneurs.

Furthermore, the path coefficient value of the effect of culture on business success $\left(\mathrm{H}_{7}\right)$ of the informal women micro-entrepreneurs indicate a positive statistical relationship $(\beta=0.102$, $\mathrm{p}=0.029$ ), implying that culture has an aggregate influence on the business success of the informal women entrepreneurs.

This present findings support the previous literature (Al-Mamun, 2019b; Zainol, et al., 2018; Nasuredin, et al., 2016; and Baron \& Markman, 2003), that examines the disaggregated effect of entrepreneurial competencies among micro-entrepreneurs in different contexts. 
Table 5: Result of the Hypotheses Testing for moderation

\begin{tabular}{llccccl}
\hline & & & Std. & & \\
& Path relationships & Std Beta & Error & t-values & p-values & Decision \\
\hline $\mathrm{HM}_{1}$ & EPT*Culture -> BSC & -0.096 & 0.058 & 1.663 & 0.049 & Not Supported \\
$\mathrm{HM}_{2}$ & ERP*Culture -> BSC & 0.111 & 0.062 & 1.800 & 0.036 & Supported \\
$\mathrm{HM}_{3}$ & ESG*Culture -> BSC & -0.078 & 0.051 & 1.541 & 0.062 & Not Supported \\
$\mathrm{HM}_{4}$ & EGZ*Culture -> BSC & 0.024 & 0.057 & 0.414 & 0.339 & Not Supported \\
$\mathrm{HM}_{5}$ & ECM*Culture -> BSC & -0.149 & 0.064 & 2.319 & 0.010 & Not Supported \\
$\mathrm{HM}_{6}$ & ECP*Culture -> BSC & -0.007 & 0.058 & 0.118 & 0.453 & Not Supported \\
\hline
\end{tabular}

Note: Business success (BSC), commitment competencies (ECM), conceptual competencies (ECP), organising competencies (EGZ), opportunity competencies (EPT), relationship competencies (ERP), strategic competencies (ESG).

Source: Author's compilation

\subsection{Moderation effects}

In terms of the interacting effects of culture on entrepreneurial competencies, the results of the path coefficients, as shown in Table 5 above, indicates that the moderating effect of culture on the dimensions of entrepreneurial competencies (i.e., conceptual, commitment, organising, opportunity, and strategic) were all above the $0.05 \%$ chosen level of significance. This signifies that the effect culture on these competencies are not statistically significant, and as such, hypotheses $\left(\mathrm{HM}_{1}, \mathrm{HM}_{3}, \mathrm{HM}_{4}, \mathrm{HM}_{5}\right.$ \& $\left.\mathrm{HM}_{6}\right)$ were not supported.

Conversely, findings confirmed that the interaction effect between culture and relationship competencies $(\beta=0.111$ and $p$-value $=0.036)$ was statistically significant at $0.05 \%$, thus confirming the hypothesised relationship $\left(\mathrm{HM}_{2}\right)$, that culture influence the relationship between relationship competencies and business success of the informal women micro-entrepreneurs in the geopolitical zone. This was consistent with the finding of Zainol, et al. (2018) and Baron \& Markman, (2003), who confirmed that entrepreneurs with good relationship competencies stand a better chance of achieving positive results in their business than those who are lacking in it.

\section{DISCUSSIONS}

Given the widely accepted notion that human beings are embodiment of culture which guides their daily lives, and the significance of entrepreneurial competencies on the success of microenterprises, this study examined the moderating effect culture on the relationship between entrepreneurial competencies and the business success of women-led enterprises in Northwest geopolitical zone of Nigeria. From the analysed data, findings on direct effects on individual dimensions of entrepreneurial competencies on business success are in agreement with previous researches (i.e., Zainol, et al., 2018; Nasuredin, et al., 2016; Baron \& Markman, 2003), that examines the effects of disaggregated effect of entrepreneurial competencies among entrepreneurs in a similar context.

Consequently, on the aspect of moderation, except for the relationship competencies where culture exerts a moderation effect, in all other identified competency areas among the informal women micro-entrepreneurs in the Northwest geopolitical zone, culture has negative and insignificant moderating effect. The significance of culture on relationship competency confirms the importance of good inter-personal skills, interactions, and networking in the business success of informal micro-entrepreneurs. This findings confirmed the report by previous researchers (Zainol, et al., 2018; Ahmad, et al., 2010; Baron \& Markman, 2003) which assert that women entrepreneurs possesses strong abilities in building solid interpersonal relationships, which they achieved through interaction with people in and outside their businesses, and their effective use of networking activities. 


\section{IMPLICATIONS AND CONCLUSIONS}

This present study on moderating role of culture on the dimensions of entrepreneurial competencies and business success of informal women entrepreneurs have both theoretical and practical implications. On the theoretical side, the paper extends Man et al.'s (2008) competency approach of examining competitive and growth-oriented firms in Hong-Kong, to the examining of the disaggregated effect of entrepreneurial competencies on the business success of informal women micro-entrepreneurs in northwest Nigeria, and by so doing, contributing to the existing body of knowledge. Secondly, the study also provides theoretical evidence on the moderating effect of culture on the relationship between entrepreneurial competencies and business success of the informal women micro-entrepreneurs.

In practical terms, the findings of the study reveals the significance of culture on relationship competencies of the informal women micro-entrepreneurs, thereby validating the importance of interpersonal skills inform of interactions, and networking activities, in the business success of micro-entrepreneurs. Thus, the study calls on government and policy makers, who wants more female owned business start-ups to include trainings on entrepreneurial competencies all entrepreneurship programmes designed for skills acquisition and vocational studies by women folks.

\section{LIMITATION AND FUTURE RECOMMENDATIONS}

In term of its limitation, the generalizability of the study is far-fetched, as respondents of the study falls within the confine of informal women micro-entrepreneurs in the Northwest geopolitical zone of Nigeria. Nevertheless, future study may extend the study to cover women entrepreneurs in small and medium enterprises, and those in other geopolitical zones, with different demographic characteristics, so as to determine the convergence validity of these constructs. Secondly, the study merely focused on entrepreneurial competencies at the individual level, future study may consider team level entrepreneurial competencies. Lastly, the data for the study was cross-sectional in nature, hence future study may consider a longitudinal data so that a deep knowledge of the constructs can be referenced.

\section{REFERENCES}

Ahmad, N. H., Ramayah. T., Wilson, C. \& Kummerow, L. (2010). Is entrepreneurial competency and business success relationship contingent upon business environment? International Journal of entrepreneurial Behaviour \& Research, 16(3), 182-203.

Ahmad, N. H., Wilson, C., \& Kummerow, L. (2011). Assessing the dimensionality of business success: The perspectives of Malaysian SME owner-managers. Journal of Asia-Pacific Business, 12(3), 207-224.

Al-Mamun, A. A., Fazal, S. A., \& Zainol, N. Z. (2019a). Economic vulnerability, entrepreneurial competencies, and performance of informal micro-enterprises. Journal of Poverty, (3), 1-22

Al-Mamun, A. A., Muniady, R., Fazal, S. A., \& Malarvizhi, C. A. (2019b). Micro-enterprise development training and entrepreneurial competencies among low-income households in Malaysia. Asia Pacific Journal of Innovation and Entrepreneurship, 13(3), 354-366

Al-Mamun, A., Saufi, R.A. \& Ismail, M.B. (2016). Human capital, credit, and start-up motives: a study among rural micro-enterprises in Malaysia. The Journal of Developing Areas, 50 (4), 383-400.

Baron, R. A., \& Markman, G. D. (2003). Beyond social capital: The role of entrepreneurs' social competence in their financial success. Journal of Business Venturing, 18(1), 4160.

Baron, R.M. and Kenny, D.A. (1986). The moderator-mediator variable distinction in social psychological research: conceptual, strategic, and statistical considerations. Journal of Personality and Social Psychology, 51(6), 1173-1182.

Baum, J.A. \& Singh, J.V. (1994). Evolutionary Dynamics of Organizations. Oxford University Press, Oxford. 
Becker, J. M., Klein, K., \& Wetzels, M. (2012). Hierarchical latent variable models in PLSSEM: guidelines for using reflective-formative type models. Long Range Planning, 45(5), 359-394.

Bird, B. (1995). Toward a theory of entrepreneurial competency. Advances in entrepreneurship, firm emergence and growth, 2(1), 51-72.

Chaiyabut, P. (2013, August). The effect of the national culture on the international business. In Proceedings of World Academy of Science, Engineering and Technology (80), 821834.

Clugston, M., Howell, J. P., \& Dorfman, P. W. (2000). Does cultural socialization predict multiple bases and foci of commitment? Journal of management, 26(1), 5-30.

Dermol, V. (2010). Development of entrepreneurial competences through a framework of competitiveness. Journal of Small Business and Entrepreneurship, 23(3), 257-276

Dillman, D. A. (2011). Mail and Internet surveys: The tailored design method--2007 update with new Internet, visual, and mixed-mode guide. John Wiley \& Sons.

Dorfman, P. W. \& Howell, J. P. (1988). Dimensions of national culture and effective leadership patterns: Hofstede revisited. Advances in International Comparative Management, (3), 127-150.

Ergeneli, A., Gohar, R., \& Temirbekova, Z. (2007), Transformational leadership: its relationship to culture value dimensions. International Journal of Intercultural Relations, 31, 703-724.

Frank H., Keßler A., \& Fink M., (2010). Entrepreneurial Orientation and Business Performance - A Replication Study. Schmalenbach Business Review. 62(2), 175-198.

Gill, A., \& Biger, N. (2012). Barriers to small business growth in Canada. Journal of Small Business and Enterprise Development, 19(4), 656-668.

Gorgievski, M. J., Ascalon, M. E., \& Stephan, U. (2011). Small business owners' success criteria, a values approach to personal differences. Journal of Small Business Management, 49(2), 207-232.

Gupta, R. (2010). Putting entrepreneurial in the limelight: is entrepreneurial competency the silver bullet for SME triumph? Review of Business \& Technology Research (RBTR) 3 (1), 377.

Hair, J. F., Hult, G. T. M., Ringle, C. M., \& Sarstedt, M. (2014). A primer on partial least squares structural equation modeling (PLS-SEM). Thousand Oaks: Sage Publications

Hayton, J. C., George, G., \& Zahra, S. A. (2002). National culture and entrepreneurship: A review of behavioral research. Entrepreneurship theory and practice, 26(4), 33-45

Henseler, J., Ringle, C. M., \& Sinkovics, R. R. (2009). The use of partial least squares path modeling in international marketing: new challenges to international marketing. Advances in International Marketing, 20, 277-319.

Hofstede, G. (1980). Culture's consequences: International differences in work-related values. Beverly Hills, Calif.: Sage Publications

Hofstede, G. (2001). Culture's consequences: Comparing values, behaviors, institutions, and organizations across nations Sage Publications, Inc.

Hughes, K. D., Jennings, J. E., Brush, C., Carter, S., \& Welter, F. (2012). Extending women's entrepreneurship research in new directions. Entrepreneurship Theory and Practice, 36(3), 429-442

Kaur, H. \& Bains, A. (2013). Understanding the concept of entrepreneur competency. Journal of Business Management \& Social Sciences Research, 2(11), 31-43.

Komppula, R. (2004). Success and growth in rural tourism micro-businesses in Finland: Financial or life-style objectives. Small firms in tourism, 115-138.

Kozan, M.K., Oksoy, D. \& Ozsoy, O. (2012). Owner sacrifice and small business growth. Journal of World Business, 47(3), 409-419.

Kreiser, P. M., Marino, L. D., Dickson, P., \& Weaver, K. M. (2010). Cultural influences on entrepreneurial orientation: the impact of national culture on risk taking and Proactiveness in SMEs. Entrepreneurship Theory and Practice, 34(5), 959-983.

Laguna, M., Wiechetek, M., \& Talik, W. (2012). Competencies of managers and their business success. Central European Business Review, 1(3), 7- 21 
Lans, T., Verstegen, J. \& Mulder, M. (2011). Analysing, pursuing and networking: a validated three- factor framework for entrepreneurial competence from a small business perspective. International Small Business Journal, 29(6), 695-713

Man, T. W. Y., \& Lau, T. (2000). Entrepreneurial competencies of SME owner/managers in the Hong Kong services sector: a qualitative analysis. Journal of Enterprising Culture, 8(3), 235-254.

Man, T. W. Y., Lau, T., \& Snape, E. (2008). Entrepreneurial competencies and the performance of small and medium enterprises: an investigation through a framework of competitiveness. Journal of Small Business \& Entrepreneurship, 21(3), 257-276.

Man, T. W., Lau, T., \& Chan, K. F. (2002). The competitiveness of small and medium enterprises: A conceptualization with focus on entrepreneurial competencies. Journal of business venturing, 17(2), 123-142.

Solesvik, M. Z. (2012, May). Entrepreneurial competencies in emerging economy context, 17th Nordic Conference on Small Business Research, Helsinki, 22-25

Michalko, M. (2000). Thinking out of the box. Retrieved September 1, 2015, from http://www.winstonbrill.com/bri1001/html/article_index/article/451-500/article472 body.html

Mitchelmore, S. \& Rowley, J. (2013). Entrepreneurial competencies of women entrepreneurs pursuing business growth. Journal of Small Business and Enterprise Development, 20(1), $125-142$

Mitchelmore, S., Rowley, J., \& Shiu, E. (2014). Competencies associated with growth of women-led SMEs. Journal of Small Business and Enterprise Development, 21(4), 588 $-601$

Nasuredin, J., Halipah, A. H., \& Shamsudin, A. S. (2016). The effect of organizational culture on the relationship between entrepreneurial competencies and SMEs business performance in Malaysia. Journal for Studies in Management and Planning, 2(11), 177-189

Noor, H. A., Hasliza, A. H. \& Siti, R. M. Z. (2010). Is entrepreneurial competency the silver bullet for SME success in a Developing Nation? International Business Management, $4(2), 67-75$

Okpara, J. O. \& Wynn, P. (2007). Determinants of small business growth constraints in a SubSaharan African Economy. SAM Advanced Management Journal, 12, 23-31

Oyeku, O. M., Oduyoye, O., Asikhia, O., Kabuoh, M., \& Elemo G. N. (2014). On entrepreneurial success of small and medium enterprises (SMEs): a conceptual and theoretical framework. Journal of Economics and Sustainable Development, 5, 14- 23

Peng, D. X., \& Lai, F. (2012). Using partial least squares in operations management research: A practical guideline and summary of past research. Journal of Operations Management, 30(6), 467-480.

Permarupan, P. Y., Al Mamun, A., Rajennd, A., Muniady, L., \& Saufi, R. A. (2016) Entrepreneurial competencies among Malaysian micro-entrepreneurs: a crossindustry and cross-state comparison. Proceedings of the International Conference for Bankers and Academics, Dhaka, 589-596

Ratten, V. (2016). Female entrepreneurship and the role of customer knowledge development, innovation outcome expectations and culture on intentions to start informal business ventures. International Journal of Entrepreneurship and Small Business, 27(2/3), 262-272.

Richard, P. J., Devinney, T. M., Yip, G. S., \& Johnson, G. (2009). Measuring organizational performance: Towards methodological best practice. Journal of management, 35(3), 718-804.

Rowe, K. (2002, October). The measurement of latent and composite variables from multiple items or indicators: applications in performance indicator systems. In Background paper prepared for keynote address presented for the Royal Melbourne Institute of Technology Statistics Seminar Series.

Sahban, M. A. (2016). Determinants of entrepreneurial intention among business students in Indonesia [Universiti Utara Malaysia]. http://etd.uum.edu.my/6338/1/s95028_01.pdf 
Sahban, M. Amsal, Dileep Kumar, M., \& Sri Ramalu, S. (2014). Model Confirmation through Qualitative Research: Social Support System toward Entrepreneurial Desire. Asian Social Science, 10(22), 17-28. https://doi.org/10.5539/ass.v10n22p17

Sajilan, S., \& Tehseen, S. (2015). Cultural orientations, entrepreneurial competencies and SMEs business success: the contingent roles of environmental turbulence and network competence. Review of Integrative Business and Economics Research, 4(2), 20-35

Sanchez, J. (2012). The influence of entrepreneurial competencies on small firm performance. Latin American Journal of Psychology, 44(2), 165-177.

Santandreu-Mascarell, C., Garzon, D. \& Knorr, H. (2013). Entrepreneurial and innovative competences, are they the same? Management Decision, 51(5), 1084-1095.

Schneider, K. (2017). Entrepreneurial Competencies of Women Entrepreneurs of Micro and Small Enterprises. Science Journal of Education, 5(6), 252-261

Simpson, M., Padmore, J., \& Newman, N. (2012). Towards a new model of success and performance in SMEs. International Journal of Entrepreneurial Behavior \& Research, 18(3), 264-285.

SMEDAN (2014). Annual abstracts of statistics: Nigeria's small and medium scale enterprises in Nigeria. Abuja, Nigeria.

Sparrow, P.R. \& Makram, H. (2015). What is the value of talent management? building valuedriven processes within a talent management architecture. Human Resource Management Review, 25(3), 249-263.

Spencer-Oatey, H. (2008). Culturally speaking second edition: Culture, Communication and Politeness Theory. Bloomsbury Publishing.

Tang, J., Kacmar, K.M. \& Busenitz, L. (2012). Entrepreneurial alertness in the pursuit of new opportunities, Journal of Business Venturing, 27(1), 77-94.

Thompson, J., \& Richardson, B. (1996). Strategic and competitive success: towards a model of the comprehensively competent organization. Management Decision, 34(2), 5-19.

Ulhoi, J.P. (2005). The social dimensions of entrepreneurship. Technovation, 25(8), 939-946.

Walker, E., \& Brown, A. (2004). What success factors are important to small business owners? International Small Business Journal, 22(6), 577-594.

Wong, A., \& Tjosvold, D. (2006). Collectivist values for learning in organizational relationships in China: The role of trust and vertical coordination. Asia Pacific Journal of Management, 23(3), 299-317.

Zainol, N.R., Al Mamun, A., Ahmad, G., \& Simpong, D. B. (2018). Human capital and entrepreneurial competencies towards performance of informal microenterprises in Kelantan, Malaysia. Recent Issues in Economic Development, 11(4), 31-50. 